John Osburg, Anxious Wealth: Money and Morality Among China's New Rich, Standford, Standford University Press, 2013, 248 pp.

\title{
Emilie Tran
}

Translator. Will Thornely

\section{(2) OpenEdition}

\section{Journals}

\section{Electronic version}

URL: http://journals.openedition.org/chinaperspectives/6749

DOI: $10.4000 /$ chinaperspectives. 6749

ISSN: 1996-4617

\section{Publisher}

Centre d'étude français sur la Chine contemporaine

\section{Printed version}

Date of publication: 1 June 2015

Number of pages: $68-69$

ISSN: 2070-3449

\section{Electronic reference}

Emilie Tran, « John Osburg, Anxious Wealth: Money and Morality Among China's New Rich, », China Perspectives [Online], 2015/2 | 2015, Online since 01 January 2017, connection on 23 September 2020 URL : http://journals.openedition.org/chinaperspectives/6749; DOI : https://doi.org/10.4000/ chinaperspectives. 6749 


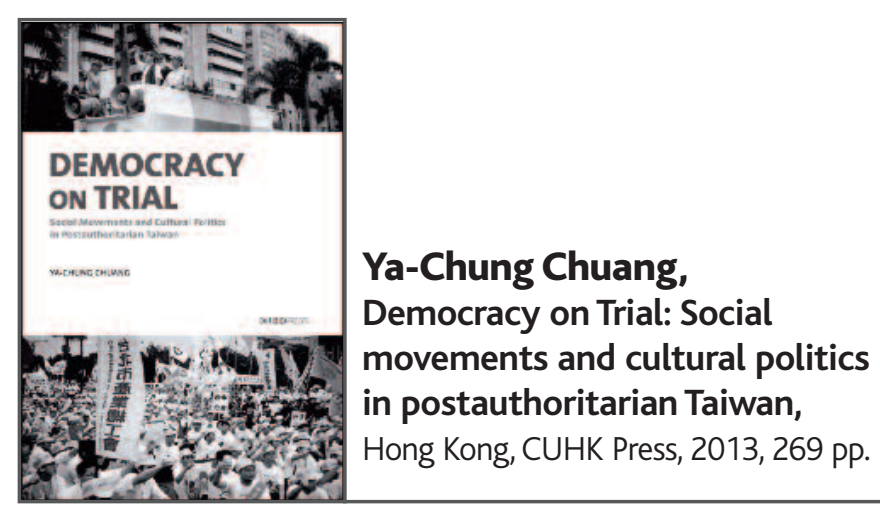

GUNTER SCHUBERT

7 he "Sunflower Movement" of spring 2014 has re-activated much scholarly interest in the world of Taiwan's social movements, which had somewhat declined over recent years. Ya-Chung Chuang's book, although published before the events leading to the occupation of the Legislative Yuan last year, is therefore timely. One of its major intentions is to highlight the importance of a vital civil society and self-confident social movements for a stable and healthy Taiwanese democracy. Chuang is an anthropologist (teaching at Taiwan's National Chiao Tung University), and he has written, as he notes himself, an anthropology of Taiwan's democracy by looking at the relationship between state and civil society (Part I), identity and ethnicity (Part II), and place and politics (Part III). The six Chapters deal with topics covering a wide range of issues that the author has investigated since his days as a young researcher doing ethnographic studies in downtown Taipei. In Chapter One, he looks back at the 1980s and early 1990s when the Nationalist Party, the KMT, opened up the political system, entailing a new sense of community through which Taiwan's society became deeply politicised. Chapter Two looks at the professionalisation of Taiwan's social movements under these new conditions, which gave leeway for unexpected alliances between older and newly founded NGOs and triggered a political awakening among movement members. Soon many of them opted to cooperate with the state and push reforms from the top down. This cooperation, however, was critically observed by others who insisted on a strategy of persistent change from below - a cleavage within Taiwan's social movements that plagues them to this day. Chapter Three traces the formation of a vibrant civil society by looking at the rise and significance of "talking public" in the 1990s, i.e., the politicisation of everyday life in Taiwan during that time. Chapter Four looks back at the highly controversial construction of bentu-identity starting in the early 1990s as both an intellectual project and a courageous undertaking of many social movements. Chapter Four continues this investigation by looking at those "ethnicities" that presented a counter-narrative to the bentu (fulao)-ideology: the Hakka minority and the aborigines. The rest of the book reflects on the authors' field research in the 1990s and early 2000s, which was motivated by his attempt to explain the meaning of place in the production of community in democratic Taiwan, and the role that the politicisation of the neighbourhood (shequ) has played in this process. In Chapters Five and Six, he reports on neighbourhood mobilisation in Taipei's Yongkang Street over a time span of some ten years in which he participated as both an activist and researcher. The epilogue engages the question of what the book's findings can tell about the contribution of Taiwan's young democracy "to a possible notion of Chinese democracy in the PRC."This late question comes somewhat unexpected in light of the author's intention, spelled out early in the book, to critically discuss the nexus of democracy and social movements in Taiwan proper. However, Foucault's spectre, as Chuang poses it, justifies such a reflection, as China "has transformed into an internal and political issue deeply integrated in fierce local, and necessarily regional and global, power struggles." China is conquering the brains of the Taiwanese, one could say, and the author insinuates in the final passages of his book that Taiwan's political and economic establishment is far from ready to defend Taiwan's democracy under this kind of manipulative pressure. It is only "qi-powered collective action" by a lively civil society that ensures the critical potential within a community necessary to defend democratic dreams, political alternatives, and multicultural ideas a potential that will, at some point, cross the Taiwan Strait to initiate a similar grassroots or bottom-up politicisation on the Chinese mainland as well.

This book targets (and needs) a reader who is rather well informed about Taiwan's post-authoritarian political and cultural transformation. It is, at least in some parts, no easy read: the author often employs the "postmodern speak" of his discipline, which for a political scientist, at least, often sounds artificially, and unnecessarily, evasive. However, I read through this anthology with much pleasure, as it reminded me of a time in which Taiwan's democracy was still pretty much a project to be shaped by concerned and idealistic citizens. Ya-Chung Chuang was part of this project, and one can easily feel by his writing how much he still is fascinated by those days, even though he always keeps a distance between himself as an observer and the social movement world that he describes. His book is certainly enriching for the study of Taiwan's social movements and their significance for democratic change and cultural transformation in the postauthoritarian era. Although it does not produce many new insights, the specific theoretical perspective and the empirical data of the third part make it a valuable study for Taiwan scholars, especially from the fields of anthropology, sociology, and political science.

I Gunter Schubert is professor at the Institute of Asian and Oriental Studies and director of the European Research Center on Contemporary Taiwan (ERCCT) at Tübingen University (gunter.schubert@uni-tuebingen.de).

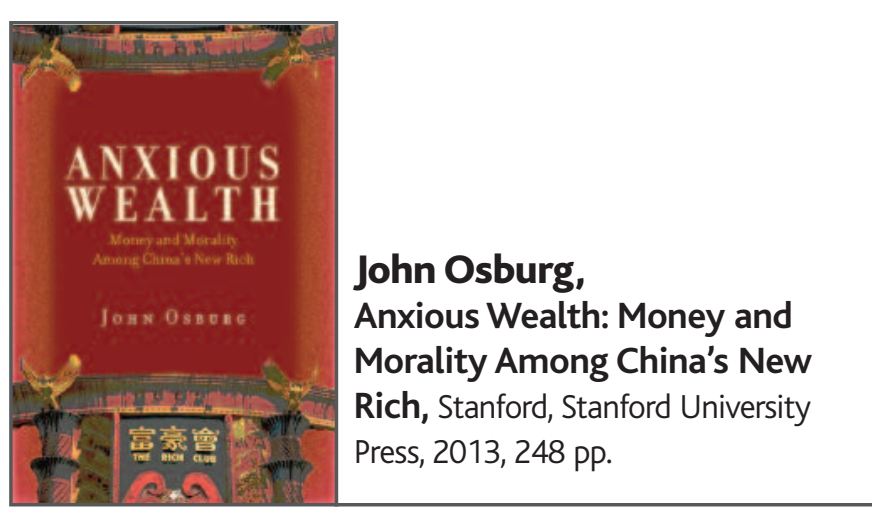

\section{ÉMILIE TRAN}

ohn Osburg's work was published at a time when China was engaging in an unprecedented anti-corruption campaign targeting "tigers and flies." A far cry from the media headlines trumpeting the fall of the latest tiger, Anxious Wealth is an ethnography of the world of the "flies," 
and in particular entrepreneurs, in China. Based on a field study he carried out in Chengdu, the author sheds light on the habitus of the entrepreneurs with whom he spent time in the capital of Sichuan.

The introductory chapter duly defines the subject of the research and sets out the inherent theoretical framework. Taking the concepts of networks and guanxi as the starting point, the author proposes a closer examination of human relations, whether based on shared interests or defined by the roles assumed by men and women, finally exploring corruption and the state. Each of the four subsequent chapters looks at specific aspects of these relations, thus helping to define, over the course of the book, the habitus of Chinese entrepreneurs with regard to money and morality.

The second Chapter, "'Entertaining is My Job': Masculinity, Sexuality, and Alliances Among Chengdu's Entrepreneurs," immerses the reader in the environment of codified pleasures of massage parlours, saunas, and karaoke bars in post-Mao China, and explains how business relations are built up and maintained, literally based on women's bodies.

Chapter 3, "'Relationships Are the Law': Elite Networks and Corruption in Contemporary China," tangibly illustrates two ways in which the power of elites is exercised, on the one hand via privatisation of the state or, in other words, the appropriation of public property by elites who do not operate in the public sphere, and on the other, via penetration by cooptation by members of the mafia, with whom the author had the opportunity to rub shoulders. Osburg thus aims to demonstrate that the formation of networks and the extension of power do not take place directly in exchange for money, but involve multiple ways of exercising power and values expressed in many forms.

Chapter 4, "From Fruit Plates to License Plates: Consumption, Status, and Recognition Among Chengdu's Elite," examines the way of life led by entrepreneurs who have succeeded, and the distinction that exists between the "bling-bling" new rich and more educated and cultured individuals who seek to set themselves apart. Although the latter criticise the diktat of the flaunting of luxury products and the ways in which they are consumed, they cannot escape it, because it is precisely these social practices that allow their peers to recognise them, and therefore their status, in the successful entrepreneurs' club.

The final chapter, "Women Entrepreneurs and the 'Beauty Economy': Sexuality, Morality and Wealth," looks at the role of women, and in particular those described by He Qinglian as "grey women" (huise nüxing) in an essay written in 1997.(1) These women are considered to be neither totally "white" and pure, like married women and legitimate future wives, nor completely "black," like the prostitutes associated with the shady world of the sex industry. Grey women are the mistresses and second wives (ernai) of rich and powerful men, and the hostesses and escorts in certain bars, restaurants, and massage parlours. Using the most basic capital, constituted by their own body, they try to gain the maximum profit they can while still in possession of their youth and beauty. In this regard, they too are entrepreneurs, in the "beauty economy" (meinü jingji).

The immoral behaviour of grey women, the excesses of officials, and the dishonesty of businessmen are all factors that contribute to the inevitable depreciation and decline in moral values in present-day China. Yet no society can survive in a complete absence of morality, and rather than lamenting the plain and simple loss of these values, the author maintains that they have been redefined under the effect of the profound changes that have shaped post-Mao Chinese society. In his concluding chapter, Osburg advances the notion of suzhi (personal quality) to measure the degree of morality and responsibility demonstrated by the players with respect to the public. Osburg therefore proposes that, rather than judging a certain businessman, political leader, or grey woman for his or her private actions, they should rather be considered according to how their wrongdoings or good deeds affect the public. While there is no evil in displaying one's social status with a luxury car, driving too fast, knocking over pedestrians, and fleeing the scene would show a lack of suzhi. Keeping a mistress or being a grey woman does not mean that the man or woman in question leads a depraved life. On the other hand, the same entrepreneurial new rich man or woman can demonstrate their high degree of suzhi by sponsoring charitable organisations. As defined, suzhi, argues the author, is very similar to the notion of "producer of life" (yangsheng) present in several philosophical Chinese traditions, or indeed the ideal of the Confucian businessman (rushang). For anyone with close or distant links with Chinese society today, Anxious Wealth does not contain, in itself, any revelations: the practices and lifestyles of some of these leaders, entrepreneurs, and grey women can be seen at first hand by the attentive observer, and the media are full of news stories relating to this field. Similarly, the cinema and television content of mainland China is, like anywhere else, a reflection of its times and of the morals that hold sway. It necessarily deals with these questions, often implicitly, but also more openly, as in the four-part documentary on the current anti-corruption campaign, entitled Zuofeng jianshi yongyuan zai lushang (Relentlessly ensuring the integrity of the state). Produced by the Party's Central Commission for Discipline Inspection and broadcast on CCTV in late 2014, this documentary recounts all kinds of setbacks and the debauchery of officials who have already been sentenced for corruption offences or are currently awaiting sentencing. However, for anyone from another geographical area of study, Osburg's work offers a good introduction to the ways of life, value system, and power games of a certain category of Chinese entrepreneur and new rich.

\section{Translated by Will Thornely.}

IÉmilie Tran is associate professor at the University of Saint Joseph in Macau, where she heads the Department of Public Administration and International Relations (emilie.tran@usj.edu.mo).

1. He Qinglian, "Huise nüxing ji qita: yuanshi jilei shiqi de zhong shengxiang" (Grey women and others: The social creatures emerging from the period of primitive accumulation), Zhongguo Baogao Zhoukan (China Report Weekly), 8 January 2005 [1st publication, 1997], www.chinaweek.com/html/2358.htm (accessed on 15 April 2015). 